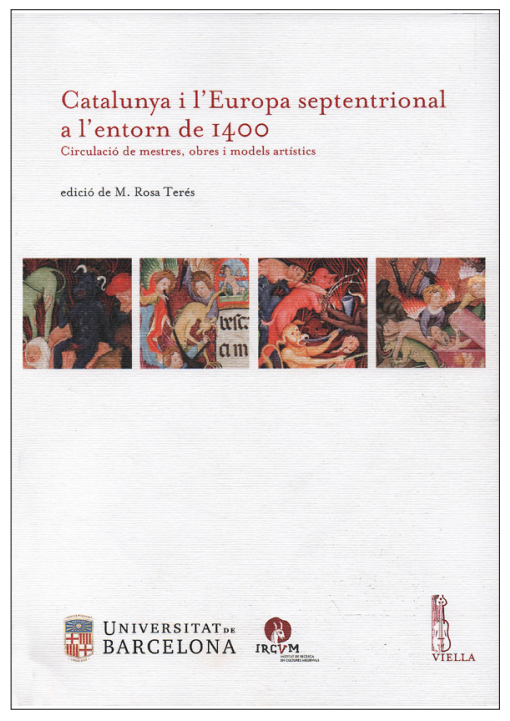

\section{Rosa Terés}

Catalunya i l'Europa septentrional a l'entorn del 1400. Circulació de mestres, obres i models artístics

\section{Universitat de Barcelona / IRCVM, Viella, 2016}

La publicació elaborada per membres i collaboradors del grup d'investigació IRCUM i editada a cura de M. Rosa Terés respon a I'objectiu explícit de demostrar la gran plenitud creativa que va caracteritzar I'art de la Corona d'Aragó a I'entorn de I'any 1400 i $d$ 'evidenciar que sobretot va estar caracteritzat per la poderosa influència que exercí la sumptuosa cultura artística cortesana de I'Europa septentrional, que matisà i establí un diàleg elegant amb les influències italiana i mediterrània més arrelades.

D'acord amb el propòsit de I'obra de rastrejar aquesta influèn- cia, en les diverses aportacions que la configuren batega la idea de centralitat de l'art francoflamenc a I'hora d'explicar les característiques del gòtic català posterior a la pesta negra, sigui concretat en el paper que artistes d'aquelles latituds desenvoluparen a la Corona d'Aragó o en la incorporació d'idees estètiques i models artístics provinents del nord. Es tracta, per tant, d'un recull calidoscòpic de relats de circulació i d'intercanvi que aplega diferents mostres, tant de viatges físics d'artistes (quan ha estat possible trobar-ne registres documentals) com de periples virtuals d'idees foranes que es fan evidents en la identificació de trets estilístics francoflamencs en obres d'art locals.

La gran presa de partit del volum a I'hora d'escometre I'objectiu esmentat és la constatació $d$ 'aquesta influència septentrional en les disciplines artístiques més diverses, enteses encertadament en un sentit ampli, tot reivindicant la rellevància explicativa de llenguatges sovint menystinguts en la historiografia de I'art, com ara l'orfebreria, els brodats, els tapissos o la miniatura. Resulta cridanera l'absència de les grans arts plàstiques hegemòniques, atès que la pintura apareix únicament representada per la il.luminació de manuscrits, mentre que l'escultura i I'arquitectura també hi tenen una presència poc protagonista i apareixen relegades, respectivament, a la seva versió en fusta o al relleu arquitectònic i a formes decoratives ben concretes. A més d'una idea de justícia historiogràfica en qüestionar la separació entre I'artesania i les belles arts i reagrupar totes aquestes disciplines en I'objecte d'estudi de la història de I'art, la consistència explicativa que es desprèn de la seva anàlisi és ben robusta.

Malgrat aquesta varietat de disciplines tractades, és immediat constatar que totes aquestes aproximacions tenen en comú un caràcter àulic decidit i ajustat al paper pioner de les Corts en la comitència i el foment de les arts en el moment històric analitzat.

D'acord amb això, els autors vinculen ben sovint la recepció de les influències artístiques septentrionals amb les inclinacions polítiques i culturals de la cort aragonesa en l'època dels darrers monarques del Casal de Barcelona $\mathrm{i}$ dels primers de la dinastia dels Trastàmara. No resulta estranya I'aparició recurrent en els textos de la figura decididament francòfila de Joan I el Caçador, emparentat per prometatges i matrimonis amb les corts franceses i borgonyones de les quals irradia l'estil del 1400; ell esdevé, juntament amb la seva dona, un gran demandant de I'art refinat i luxós, amb què cercava d'embellir i significar la vida cortesana mateix.

Enmig de l'esmentat calidoscopi d'històries de circulació de productes artístics i d'idees estètiques, Montserrat Aymerich presenta la vida i I'obra de Jaume Copí, un brodador flamenc que estigué durant una llarga temporada al servei dels darrers reis pertanyents al Casal de Barcelona (Pere el Cerimoniós i els seus fills, Joan el Caçador i Martí l'Humà) i de les seves 
famílies per tal de confeccionar-los les vestidures amb el sumptuós estil flamenc de l'època. L'autora, centrada en una disciplina tan funcional com el brodat, lluita contra la manca de vestigis materials tot vinculant feliçment els documents de I'època que recullen els encàrrecs amb una anàlisi acurada i rigorosa de les tècniques dels brodadors $\mathrm{i}$ també amb l'aspecte dels vestits sumptuosos en les detalladíssimes obres pictòriques del període, que els representen amb molta cura.

Joan Domenge i Mesquida explica la presència física d'orfebres d'origen septentrional a la Corona d'Aragó (c. 1380-1420) a partir de la consolidació de la demanda per part dels membres de la cort d'aquest tipus de productes, essencials en la configuració del luxe i la distinció que pretenien i que amb anterioritat era satisfeta per marxants. La sumptuositat i I'anomenada d'aquestes obres, de ben segur diferenciades d'una producció local menys refinada, ens ha proporcionat la pervivència d'algunes descripcions i de certa presència documental d'alguns dels artistes, fets que permeten a l'autor reconstruir processos i biografies, tot i ser una disciplina amb I'obra completament perduda. És així com coneixem els negocis dels proveïdors de les reines Violant de Bar i Maria de Luna, la instal.lació d'argenters alverns a Barcelona o les comandes que satisferen argenters i orfebres nòrdics que establiren tallers a Barcelona o a València, com ara Teodoric de la Vort, Lluís Boteus, Rigaut Sauter, Hans Tramer i, fins i tot, artistes amb vinculació laboral contínua amb la cort, com ara Anaquí Augeni i Jacomí de Riya. Malgrat el desconeixement físic de I'objecte, la novetat, la vistositat i la singularitat de les joies que aquests artistes septentrionals elaboraren ens permeten establir un vincle innegable entre la sumptuositat i el refinament i I'estètica septentrional que podem observar en altres disciplines.

Rafael Cornudella fa una anàlisi panoràmica de la il.luminació de manuscrits a Catalunya al tombant dels segles XIV i XV, una època $d$ 'intensa renovació en la miniatura, que resulta ben explicativa dels processos d'intercanvi artístic que s'esdevenen en l'àmbit de la pintura en general. La demanda de IIibres luxosos de monarques com Joan I i Martí I respon a les mateixes motivacions d'assoliment de prestigi que I'orfebreria o el brodat, i també en aquest cas el paper $d^{\prime}$ artistes septentrionals fou essencial, fins al punt de constituir un dels principals vehicles de difusió de la nova estètica pictòrica francesa i flamenca. Tot i que encara s'ha de fer un treball exhaustiu que tracti de I'arribada dels Ilibres de luxe a Catalunya demanats per la cort i I'alta noblesa, la seva influència es pot rastrejar en el canvi que s'origina en la miniatura catalana, que fins llavors estava protagonitzada per una forta arrel italianitzant. Així, en aquest cas no es tracta tant d'un viatge físic d'artistes, sinó que el periple el duen a terme les idees estètiques. La lluita contra la manca d'obres i d'atribucions segures no impedeix que I'au- tor entri a valorar la influència de pintors flamencs com Jacques Coene (que despertà un insistent interès en el rei Joan) o d'altres de qui sabem poc més que el nom (com ara Marçal de Sas o Alà lo Ros) sobre la interessant obra en plena evolució d'il.luminadors locals com el Mestre del Breviari de Martí I'Humà, el Mestre de Galceran de Vilanova o Rafael Destorrents, autor documentat del Missal de Santa Eulàlia.

La sumptuosa producció de tapissos figurats de terres del nord tampoc no passà gens desapercebuda en les pretensioses corts dels monarques de la Corona d'Aragó del voltant del 1400, tal com refereix Jacobo Vidal Franquet en el capítol que dedica als mestres tapissers septentrionals a la Corona d'Aragó medieval. A més d'importar directament obres de París, Brussel.les i Arràs, I'autor documenta la presència de mestres del nord al sud dels Pirineus per elaborar tapissos d'alt Iliç que els tallers locals no duien a terme, i també molt possiblement per tenir cura dels que havien estat importats anteriorment. La desaparició de la seva obra i la seva existència purament documental no ens permet entrar a valorar el paper de tapissers com Joan lo Ros, Joan de Brussel-les o Robinet. Sí que tenim, però, moltes evidències que ja més avançat el segle XV arrelaren a la Corona d'Aragó uns quants obradors locals, però de ben segur no arribaren a la qualitat dels tallers francoflamencs.

D'altra banda, és interessant com I'autor resitua el paper de 
I'elaboració de tapissos en relació amb la jerarquia de disciplines de la història de I'art, quan afirma que el luxe que porten associats aquests productes refinats d'alt Iliç i el paper central de la iconografia representada a I'hora de prendre les decisions de compra obliguen a relativitzar el rol de l'estètica en la generació d'aquesta demanda i, en conseqüència, a aigualir la seva funció de transmissió de models pictòrics.

Resulta ben suggestiu I'article $d^{\prime}$ Antoni Conejo, atès el precís exemple d'adopció de formes artístiques oposades a la tradició local, quan analitza la introducció -en la sòbria arquitectura meridional pròpia del gòtic català - d'un intrús decorativista septentrional com són les formes flamejants. Lluitant contra les sobrerestauracions dels darrers temps i contra atribucions d'obra fonamentades en arguments poc consistents, I'autor rastreja la gènesi d'aquestes formes en l'arquitectura catalana i se centra en la figura rellevant de Reinard des Fonoll i el seu controvertit paper en edificis tan significatius com el monestir de Santes Creus, I'església de Santa Maria de Montblanc o la catedral de Tarragona. L'estudi dels documents manuscrits, de fotografies prèvies a les restauracions i l'encreuament amb evidències estilístiques fan resituar, d'acord amb la historiografia més recent, el paper pioner d'aquest artista de plausible origen anglès en I'adopció de formes flamígeres en I'arquitectura gòtica catalana i a oferir una nova cronologia de les que eren considerades les seves obres seminals en èpoques més avançades en el temps i menys precoces en relació amb I'adopció de I'estil.

L'editora d'aquest volum, M. Rosa Terés, presenta un article que aprofundeix en la idea d'intercanvi de models en el període «internacional» del gòtic, tot analitzant I'oportunament documentat viatge de l'escultor Pere Sanglada fins a Bruges per comprar fusta i fornir-se de models per a la realització del cor de la catedral de Barcelona. No pot ser més escaient per al propòsit d'aquest volum la constància documental del viatge d'un artista cap a terres nòrdiques per tal de fornir-se tant del material físic com de l'estètic per dur a terme la seva obra, que, tot i posseir una acusada influència nòrdi$c a$, és una peça ben original i incomparable, plena de solucions que no trobem en cors contemporanis, $i$ que marcà tendència. L'autora intenta discernir de manera ben concreta quin fou l'efecte d'aquest periple de veritable «espionatge artístic» sobre I'obra realitzada i també esclarir la paradoxal similitud del cor barceloní amb els de catedrals angleses, però sense poder concloure amb suport documental cap certesa en aquest darrer punt. La detecció de solucions originals i pioneres, combinades amb fórmules inspirades en allò que Sanglada observa arreu, ens du a les portes d'una reflexió sobre la delicada dialèctica entre la creativitat individual de I'artista i les influències rebudes, una reflexió que al cap de sis segles comporta una recerca veritablement complexa.
D'altra banda, Montserrat Jardí proposa una interpretació dels relleus del claustre de la catedral de Barcelona, elaborats en una època un xic més tardana (1433-1449) i poc estudiats des del punt de vista iconogràfic en el conjunt, com a concreció en pedra d'un recull d'episodis bíblics amb vocació didàctica i moralitzadora d'acord amb els propòsits de les Bíblia pauperum o els Speculum Humanae Salvationis, manuscrits comuns a França sobretot. El fenomen d'intercanvi cultural que recull I'article aporta d'una manera especulativa un desplaçament físic concret i documentat - les estades del comitent de I'obra, el bisbe Francesc Climent Sapera, a Avinyó - com a possible moment desencadenant de I'origen d'aquest projecte iconogràfic, però més aviat s'erigeix com un bon exemple d'adopció de tendències foranes i de permeabilitat entre diferents disciplines.

Aquestes múltiples aproximacions a l'adopció de models artístics forans a la Catalunya del 1400 permeten que ens fem una idea de com s'articulava la circulació de les idees artístiques en aquesta època sovint caracteritzada, tal com ho expressa la controvertida etiqueta de «gòtic internacional», per I'intercanvi i la creació d'un estil convergent a tot Europa. Per bé que aquesta publicació defugi I'etiqueta esmentada, els diversos capítols que la integren fan ben evident la centralitat de les corts francesa i borgonyona i mostren com a inqüestionable la unívoca direccionalitat d'aquesta circulació 
artística, fet que encerta a qüestionar la idea coral que conté I'adjectiu internacional i a afirmar la preeminència francoflamenca en I'estil del 1400. Però, d'altra banda, el tractament que es dona a disciplines artístiques tan diverses permet traslladar al conjunt de les arts - de manera satisfactòriauna etiqueta tan essencialment pictòrica com aquesta d'«internacional», ja que mostra que la difusió d'un art elegant, sumptuós, refinat i estilitzat que pretén unir-se amb els substrats que troba pel camí és ben comuna a tots els llenguatges artístics que són analitzats en el volum.

En tot cas, el mosaic d'erudites i documentades intervencions que integren el llibre permeten enriquir la imatge que tenim de l'art gòtic català posterior a la pesta negra; el volum proposa diverses mirades sobre com la incorporació de nous trets artístics estilitzats i atents al decorativisme propis de l'art septentrional enriqueixen un substrat protagonitzat per la sobrietat meridional i el realisme italià. I, en ferho, es mostra perfectament allò que s'esdevé al tombant dels segles XIV i Xv en I'art europeu: I'adopció d'un nou estil que compatibilitza característiques aparentment paradoxals com el sentit naturalista i el refinament o l'internacionalisme i I'atenció als condicionaments locals.

Pau Vives Xiol

Universitat de Barcelona pauvives@hotmail.com

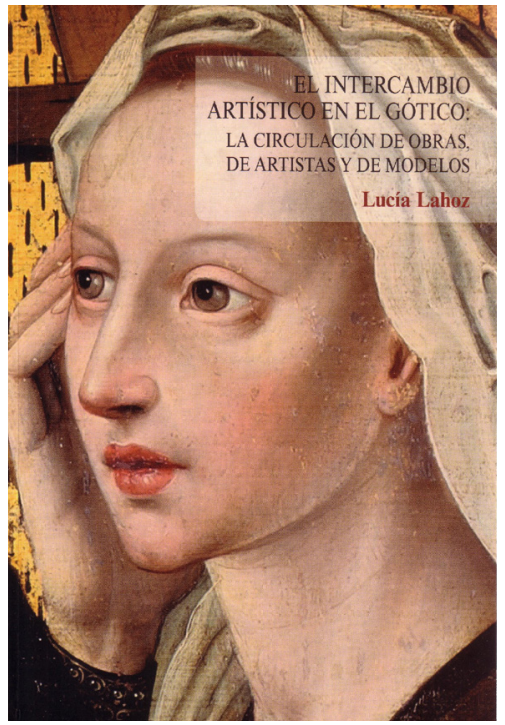

LUCÍA LAHOZ

El intercambio artístico en el gótico: la circulación de obras, de artistas y de modelos

Salamanca, Universidad Pontificia de Salamanca, 2013

El libro de la profesora Lucía Lahoz El intercambio artístico en el gótico: la circulación de obras, de artistas y de modelos, publicado en 2013, constituye un ensayo que aborda «la incidencia del fenómeno del intercambio en el arte gótico en Álava». "La razón más evidente para el nuevo estudio - advierte Lahoz - es la continua investigación de la bibliografía artística con ese enfoque sobre el tema, cuyas aportaciones, sin duda, enriquecerán la imagen final de su producción y, por tanto, nos acercará más a su realidad». El libro podría definirse como un catálogo del gótico en Álava, pues contiene análisis de objetos estéticos y de culto que resultan claves para el desarrollo del estilo en la provincia, restos y testigos de un «reino de lo imaginario y lo simbólico» poblado de las imágenes que construyeron aquella cultura. Lahoz describe el mecanismo de «aproximación mental» del artista a los modelos de sus obras como «dejà vu por el que le son dados como "arte"», de manera que su análisis de procesos artísticos trasciende a los contextos sociales donde se adaptan modas y se perpetúan tradiciones figurativas. La exposición del libro se remonta al siglo XIII y sobrepasa el $X V I$, entramando objetos como fragmentos de un discurso trazado gracias a las nociones metodológicas de centro/periferia: «catalizadores y exponentes de la creación artística» que organizan los capítulos del libro y resaltan sus interconexiones señalando las direcciones de los intercambios. Las obras se articulan entre sí, de esta manera, en una historia, como (pos)producciones de imágenes precedentes, derivaciones o sustratos de nuevas obras ligadas a personajes y lugares. En el entramado cultural que así se va ramificando desde el análisis de cada objeto, la autora despeja los caminos de opciones o elecciones posibles al alcance de los productores, para valorar en cada caso las soluciones con las que salvaron los obstáculos técnicos o ideológicos interpuestos entre cada obra y sus destinatarios.

El libro comienza presentando a los importadores de la vanguardia extranjera en Álava a través de un modelo estándar difundido en el 
Aquest article ha estat publicat originalment a Matèria. Revista internacional d'Art (ISSN en línia: 2385-3387)

Este artículo ha sido publicado originalmente en Matèria. Revista internacional d'Art (ISSN en línea: 2385-3387)

This article was originally published in Matèria. Revista internacional $d^{\prime}$ Art (Online ISSN: 2385-3387)

\section{MATÈRIA}

Revista internacional d'Art

Els autors conserven els drets d'autoria i atorguen a la revista el dret de primera publicació de l'obra.

Els textos es difondran amb la llicència de Reconeixement-NoComercialSenseObraDerivada de Creative Commons, la qual permet compartir I'obra amb tercers, sempre que en reconeguin I'autoria, la publicació inicial en aquesta revista i les condicions de la llicència: https://creativecommons. org/licenses/by-nc-nd/4.0/deed.ca

Los autores conservan los derechos de autoría y otorgan a la revista el derecho de primera publicación de la obra.

Los textos se difundirán con la licencia de Atribución-NoComercial-SinDerivadas de Creative Commons que permite compartir la obra con terceros, siempre que éstos reconozcan su autoría, su publicación inicial en esta revista y las condiciones de la licencia: https://creativecommons.org/licenses/ by-nc-nd/4.0/deed.es

The authors retain copyright and grant the journal the right of first publication.

The texts will be published under a Creative Commons Attribution-NonCommercial-NoDerivatives License that allows others to share the work, provided they include an acknowledgement of the work's authorship, its initial publication in this journal and the terms of the license: https://creativecommons.org/licenses/by-nc-nd/4.0/deed.en

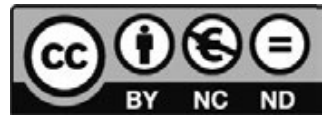

